\title{
TRÊS ETAPAS NO APERFEIÇOAMENTO DA CONDIÇÃO HUMANA NA AMÉRICA.
}

Desde longo tempo a América foi o continente de tôdas as injustiças, de tôdas as iniqüidades. Tarde descoberta, sofreu o choque da civilização. Mas um ponto do Novo Mundo suportou de maneira particular todo o pêso da violência colonial, foi - Haiti. País de eleição foi em conseqüência a terra vítima.

Depois da descoberta sucessiva do Salvador, de Cuba, Cristóvão Colombo chegou ao Haiti a 5 ou 6 de dezembro de 1492 . Ante a beleza de uma natureza incomparável, o Navegador batizou esta ilha com o nome de Hispaniola, isto é, Pequena Espanha. Melhor, fêz dela o primeiro estabelecimento dos europeus no Novo Mundo, construindo ali a Natividad com os despojos da Santa Maria. Quando voltou à Espanha para dar contas do feliz resultado de sua missão aos soberanos católicos, Colombo lá deixou uma guarnição de 39 membros que tiveram, desde a partida do almirante, a mais abominável conduta em relação aos indígenas haitianos. Estes não se deram por vencidos e, sob o comando de um de seus caciques, Caonabo, destruiram a Natividad massacrando os europeus. Em sua segunda viagem Cristóvão Colombo, comovido com o desastre e o fim trágico de seus companheiros, construiu a cidade de Isabel, outros fortes e outras cidades à medida que tomava sob seu domínio as diferentes regiões do país.

Se o sol jamais se deitou sôbre as imensas possessões dos soberanos da Espanha, a dignidade humana sofreu, à sombra dos raios dêste sol, tôdas as afrontas na pessoa dos naturais do Haiti, que foram empregados nos mais rudes trabalhos de minas e na exploração das terras. Os cronistas daquele tempo, em sua maior parte espanhóis, são unânimes em declarar que o número dos índios da ilha Hispaníola era de $1.000 .000 \mathrm{em}$ 1492, porém dez anos mais tarde restavam apenas 50.000 .

(*). - Tradução do francês por Branca Dulcina Bagueira Leal Martins Sampato (Nota da Redação). 
Em 1502 surgiu na ilha o problema da mão-de-obra. A população autóctone tendo sido exterminada, foi preciso encontrar novos braços. Foram importados da Europa homens brancos engajados por 36 meses. Foi uma escravidão atenuada do branco sôbre a terra da América que a história reteve designando sob o nome de "engajado", o indivíduo submetido ao contrato do trabalho.

Os brancos não podendo se adaptar às condições do clima de Hispaniola foram considerados incômodos. Desde então recorreu-se à Africa. Durante três séculos êste desgraçado continente forneceu milhões de seus filhos que vieram fecundar o. solo americano. Hispaniola, como outros pontos colonizados, recebeu regularmente sua quota de escravos negros. Foi o comércio de escravatura com seu cortêjo de sofrimentos, males e horrores. E esta infernal instituição continuou mesmo quando. a Espanha, pelo tratado de Basiléia, cedeu à França a parte ocidental da ilha. Esta cessão teve lugar em 1697 e Hispaniola, sob o domínio francês, trocou seu nome pelo de São Domingos.

O sistema iníqüo de escravidão mantido pelos franceses trazia em si germens de morte. Três classes compunham a população sandominguense: a classe dos brancos, a dos libertos e a dos escravos. Cada uma apresentava seus problemas próprios e reclamava alternativamente suas reivindicações por motivos diferentes. Os brancos da colônia, a exemplo dos franceses da Metrópole, exigiam sua participação ativa no govêrno e, de despeito, faziam tudo que podiam para criar obstáculos aos inglêses.

Os libertos, filhos de colonos brancos e de negras, na maior parte, sofriam todos os abusos apesar do lugar importante que ocupavam na economia colonial. Legalmente não eram cidadãos e socialmente eram objeto de tôdas as humilhações da parte dos brancos. A princípio, de modo pacífico, solicitaram da França a outorga dos mesmos direitos de que gozavam os brancos e depois para São Domingos. Não sendo atendidos, recorreram às armas a fim de dar seguimento a suas legítimas pretensões.

A classe mais numerosa e mais maltratada, a dos negros, não viu com indiferença as atividades das duas outras classes. Os brancos reclamaram vantagens políticas em virtude de leis. revolucionárias, os libertos lutaram pela igualdade civil e política, os negros escravos se revoltaram por um direito inerente à vida: "A Liberdade"! Eles usaram da fôrça. O ferro e o fogo foram os argumentos que empregaram. Destruiram habitações 
e massacraram os brancos que caíram em seu poder. Este memorável acontecimento teve lugar a 21 de agôsto de 1791 .

Desta data em diante, a conquista da liberdade pelos negros tornou-se um estado de fato devido à sua coragem. A metrópole francesa mandou comissários a São Domingos. E Sonthonax apenas confirmou a situação que dava um regulamento humano ao negro. Forçado pelas circunstâncias o comissário proclamou a abolição da escravidão em São Domingos a 29 de agôsto de 1793 .

O eco dos acontecimentos sensacionais de São Domingos chegou à França e a Convenção de Paris, por seu decreto de 4 de fevereiro de 1794 aboliu a escravidão em tôdas as colônias francesas.

Transcrevemos o texto dêsse decreto:

"A Convenção Nacional decreta que a escravidão foi abolida em tôdas as colônias francesas. E decreta em conseqüência que todos os habitantes destas colônias, de qualquer côr são cidadãos franceses e a partir dêste dia gozarão de todos êsses direitos que lhe são garantidos pela Declaração dos Direitos e pela Constituição".

Haiti, outrora São Domingos, teve o excepcional privilégio de forçar a marcha dos acontecimentos para a melhora das condições do homem negro e portanto do homem de um modo geral.

Esta brilhante etapa, inaugurada na terra do Haiti, não foi aceita sem recriminações. Uma dezena de anos mais tarde, Napoleão Bonaparte, no pogeu de seu poderio militar, revogou o decreto de abolição da escravidão e, para dar seguimento a esta medida anti-humanitária e retrógrada, organizou a mais formidável expedição para restabelecer a escravidão no Haiti. Uma vez transpostos os obstáculos que se antepõem à Liberdade, esta não se deixa mais cercear e voa cegamente em busca de seu destino fulgurante! Debalde tentaram detê-la. Surgiram hostilidades. Houve guerras assassinas. Combates sangrentos se travaram entre tropas francesas e as massas negra do Haiti. Enfim, depois de muitas lutas e sofrimentos, onde a sorte das armas oscilava duvidosa entre o heroismo dos negros colonos escravizados e as fôrças francesas organizadas, deu-se a citória da justiça sôbre a iniqüidade. O Haiti, guiado por Jean, Jacques Dessalines, Pétion, Christophe e tôda uma plêiade de bravos, proclamou sua independência a $1 .^{\circ}$ de janeiro de 1804 . 
Um nôvo estado independente era criado na América, por antigos escravos negros, após os Estados Unidos da América do Norte.

A segunda etapa teve os Estados Unidos da América por cenário. Apesar de todos os belos princípios preconizados, apesar de tôdas as nobres instituições que formam a base da democracia americana, a escravidão perdurou nesse país tornandose uma verdadeira chaga social.

Sua permanência constituia o mais formal desmentido ao sentimento de generosidade inato no homem e aos ideais professados no ato da declaração da Independência Americana.

Este anacrônico sistema de escravidão indignava os corações bem formados, feria as consciências e armava braços. A Guerra de Secessão, cujo motivo foi a escravidão moderna, pôs em luta o país americano dividindo-o em dois campos adversos.

Enfim, no dia $1 .^{\circ}$ de janeiro de 1863 , o ilustre presidente Abraão Lincoln, por um ato de elevada sabedoria política e humanitária, publicou o decreto que aboliu a escravidão em todo o território dos Estados Unidos.

Segue-se o texto dêste decreto que faz honra aos generosos sentimentos dêste grande presidente, que encontrou a morte dois anos depois sob os golpes assassinos de um fanático.

Assim, pois, a abolição da escravidão nos Estados Unidos teve seu mártir na pessoa daquele eminențe abolicionista.

"Washington. Sexta-feira, $10^{\circ}$ de janeiro de 1863. Está entendido que a 22 de setembro do ano 1862 , uma proclamação publicada pelo Presidente dos Estados Unidos estipulou as seguintes disposições:

Que a $10^{\circ}$ de janeiro do ano cristão de 1863 as pessoas possuídas como escravas, em todos os Estados e por tôda parte onde a população se revoltou contra os Estados Unidos, serão livres a partir desta data e para sempre;

Que o poder executivo dos Estados Unidos, inclusive as autoridades de terra e mar, deverão reconhecer e proteger a liberdade dessas pessoas e não entravar de nenhum modo os esforços que possam fazer para obter efetivamente sua liberdade;

Que a partir de $1 .^{\circ}$ de janeiro, o poder Executivo designará, por uma proclamação, os Estados ou Comunas 
onde a prpulação esteve em rebelião contra os Estados Unidos;

Eu, Abraão Lincoln, Presidente dos Estados Unidos, em virtude do poder de que fui investido como comandante em chefe dos exércitos de terra e mar dos Estados Unidos, no tempo da rebelião armada contra a autoridade e o Govêrno dos Estados Unidos, e como medida conveniente e necessária para a repressão desta rebelião, hoje, $10^{\circ}$ de janeiro do ano cristão de 1863 , de acôrdo com o que me propus fazer no prazo de 100 dias, ordeno e proclamo pùblicamente que os Estados e as partes dos Estados onde suas populações respectivas estão hoje em rebelião contra os Estados Unidos a saber: - O Arkansas, o Texas, a Luisiana (com exceção das paróquias de São Bernardo de Plaqueminas, de Jefferson, de St. Jean, de St. Charles, de St. Jacques, de Ascenção, de Assunção, de Terrebonne, de Lafourche, de Santa Maria, de São Martin e de Orleans, inclusive a cidade de Nova Orleans), - Mississipi, o Alabama, a Flórida, a Geórgia, a Carolina do Sul, a Carolina do Norte e a Virgínia (com exceção dos 48 condados designados como a Virginia do Oeste e também os condados de Berkelei, de Accomac, de Hampton do Norte, da cidade de Elizabeth, de York, de Princess Anne e de Norfolk, inclusive as cidades de Norfolk e Portsmouth) e os outros pontos excetuados como se esta proclamação não tivesse sido publicada.

Em virtude dos poderes, conforme o quadro descrito e para os fins acima indicados, eu ordeno e declaro que tôdas as pessoas retidas como escravos nos Estados ou nas partes dos Estados acima designadas estão doravante e estarão sempre livres, e que o Poder Executivo dos Estados Unidos, inclusive as autoridades militares e navais, reconheçam e mantenham a liberdade dessas pessoas.

Aconselho às pessoas assim declaradas livres a se absterem de tôda violência, salvo em caso de legitima defesa, e lhes recomendo que trabalhem lealmente, tanto quanto puderem (de acôrdo com suas fôrças), recebendo salários razoáveis.

Declaro, além disso, e faço saber que essas pessoas si se acharem em condições convenientes, serão aceitas no serviço do exército dos Estados Unidos para formar a guarnição dos Fortes, guardar as posições, as estações e outros lugares, e também para servir a bordo de navios de guerra de todo gênero.

Agindo assim, creio sinceramente fazer um ato de justiça garantido pela Constituição de acôrdo com as necessidades militares e invoco o julgamento refletido da Humanidade e a graça do Todo Poderoso.

A fé de que, assino a presente com minha mão e nela faço apor o sêlo dos Estados Unidos. 
Publicado na cidade de Washington, a $10^{\circ}$ de janeiro do ano cristão de 1863 e $27 .^{\circ}$ aniversário da independência dos E.U.A. Abraão Lincoln, pelo presidente William H. Seward".

A escravidão por ter durado tanto tempo deixou nos Estados Unidos sequases que, como a segregação racial, persistem ainda. E: é pena!

A terceira etapa se desenrolou no Brasil. A despeito da formidável campanha anti-escravagista travada no fim da primeira metade do século XIX através do mundo, a despeito da abolição da escravidão em tôdas as possessões francesas e inglêsas, a despeito do ato de clemência do presidente Abraão Lincoln, o Brasil conservou-se ainda na iniqüidade.

Se a escravidão no Brasil não foi das mais cruéis, o domínio de um homem sôbre outro homem é um fato de tal modo inqualificável que repugna à consciência universal .

No dia 13 de maio de 1888 a princesa imperial do Brasil, encarregada da regência de seu país, promulgou em nome do Imperador Pedro II a seguinte lei contrassinada por Rodrigo Augusto da Silva e registrada sob o n. ${ }^{\circ} 3.353$.

Eis aqui o texto lacônico dêste memorável decreto:

"A Assembléia Geral decreta:

Art. 1.0 - Está declarada, desde a publicação desta lei, a abolição da escravidão no Brasil;

Art. 2.0 - Revogam-se as disposições em contrário.

Sede do Senado, 13-5-1888.

A Princesa Imperial regente em nome do Imperador. Rodrigo Augusto da Silva".

\section{Con'clusão.}

Em pontos diferentes do continente americano, atos públicos foram realizados pelos governos respectivos para fazer triunfar e respeitar os direito do indivíduo.

Nesta obra de emancipação humana, o Haiti constitui a primeira etapa e a mais importante. As próprias vítimas daquela degradante situação quebraram suas cadeias e proclamaram seus direitos em face do mundo. A metrópole francesa nada mais fêz que sancionar um estado de fato.

Nos Estados Unidos e no Brasil, foram as consciências honestas que, desprezando interêsses materiais, provocaram a 
abolição da escravidão. A América do Norte conheceu os horrores de uma guerra civil enquanto que o Brasil foi generosamente inspirado por uma princesa de grande coração.

Os textos legislativos são os testemunhos de uma época em que a exploração física do homem estava na ordem do dia.

Apesar de tudo que já se conseguiu, ainda resta muito a fazer para que a pessoa humana possa enfim, através do mundo, gozar de tôda a plenitude de sua dignidade.

MAURICE A. LUBIN

Do "Institut Haitien de Statistique de Port-au-Prince. Haitl" 